\title{
Analysis of the Content of Macroelements in Soil and Seeds of Winter Rape (Brassica Napus Var. Napus) as a Result of Fertilization Using Two-Component Mineral Fertilizers
}

\author{
Sławomir Stankowski', Grzegorz Hury', \\ Magdalena Sobolewska', Marzena Gibczyńska² \\ 1 Department of Agronomy, West Pomeranian University of Technology in Szczecin, Poland \\ 2 Department of Chemistry, Microbiology and Environmental Biotechnology, West Pomeranian University of \\ Technology in Szczecin, Poland \\ * Corresponding author's e-mail: marzena.gibczynska@zut.edu.pl
}

\begin{abstract}
The subject of the study was an analysis of the influence of two-component mineral fertilizers of Polish, Lithuanian and Russian production on the changes in the soil $\mathrm{pH}$ and the contents of available phosphorus and potassium as well as exchangeable magnesium after winter rape cultivation and the content of macroelements in winter rape seeds. The study also focused on the effect of using varying doses of fertilizers. A two-year field experiment was carried out on soil belonging to loamy sand, the IVa bonitation class. The experimental plant was winter rape, DK EXPLICIT hybrid. The experiment was established using random blocks design in 4 replicates. Two factors were compared in the studies: I. factor -3 two-component mineral fertilizers of Russian, Lithuanian and Polish production $\left(\mathrm{POLIDAP}{ }^{\circledR}\right.$ ). II. factor -3 doses of fertilization (minimum, optimum, maximum, which were respectively: 1.0, 2.0, $3.0 \mathrm{dt}$ per hectare). Introducing the two-component fertilizers and diversification of their doses was a factor that did not change the soil acidification. The applied two-component fertilizers (Russian, Lithuanian and Polish POLIDAP ${ }^{\circledR}$ ) caused an increase in the amount of available phosphorus in the soil, with no differences depending on the fertilizer type. Diversification of the two-component fertilizers and potassium salt doses was reflected in a significant, but not proportional to the dose, increase in the amount of available phosphorus and potassium in the soil. While using fertilizers of Russian, Lithuanian and Polish production (POLIDAP $($ ) during rape cultivation, there was no difference in the nitrogen, phosphorus, magnesium and sulfur contents in the seeds of cultivated winter rape of hybrid DK EXPLICIT cv.
\end{abstract}

Keywords: soil, available phosphorus, available potassium, exchangeable magnesium, two-component mineral fertilizers

\section{INTRODUCTION}

A wide range of compound fertilizers with similar chemical composition differing in the quality and assimilation of nutrients, both import and of domestic production, are available on the Polish market. Multi-component fertilizers are characterized by a feature that each granule contains all nutrients in the declared content [Regulation (EC) No 2003/2003]. In addition to three-component fertilizers, two-component ones are also produced, containing the elements taken up by plants in the anionic form, i.e. nitrogen and phosphorus.

Implementing the correct modern agrotechnics should involve precise fertilization adapted to the potential of cultivated plants. The use of multicomponent fertilizers should be performed in a rational way, taking into account high and good quality yields as well as effectiveness of fertilization, while at the same time using the benefits of agrochemical fertilizers [Nogalska et al. 2012]. 
In Poland, the cultivation of rape is profitable and developable. In 2017, the production of rape and agrimony in Poland amounted to 2697.3 thousand tons [Statistics Poland 2018]. Rape belongs to the plants with very high fertilizing requirements (more than double the needs of cereal plants) and in autumn, it takes up significant amounts of nutrients. In order to achieve satisfactory yields, nutrients must be provided to the plants in optimal amounts and dates. Therefore, the basic agronomical condition in the cultivation of winter rape is high mineral fertilization. The most important indicators determining the fertility of soil are: $\mathrm{pH}$ and abundance in the available phosphorus, potassium and magnesium [Jadczyszyn et al. 2010]. Fertilization, affecting the soil parameters, may have also impact on the chemical composition of cultivated plants. The mineral composition of rape is primarily assessed for nitrogen, phosphorus, magnesium and calcium contents.

While applying an intensive integrated fertilization and selecting the right multi-component fertilizer, the changes in the abundance of cultivated soil should be taken into account.

The presence of two-component fertilizers of various Polish and foreign producers on the market justifies the research on the comparison of their impact on plants and qualitative changes in the soil.

The subject of the study was an analysis of the influence of two-component mineral fertilizers of Polish, Lithuanian and Russian production on the changes in the soil reaction and the contents of available phosphorus and potassium as well as exchangeable magnesium after winter rape cultivation and the content of macroelements in winter rape seeds. The study also focused on the effect of varying the doses of fertilizers used.

\section{MATERIAL AND METHODS}

\section{Experimental characteristics}

The experiment was carried out in 2015-2017 in Lipnik $\left(53^{\circ} 41^{\prime} \mathrm{N}, 14^{\circ} 97^{\prime} \mathrm{S}\right)$, at the Agricultural Experimental Station belonging to the West Pomeranian University of Technology in Szczecin. The soil belongs to loamy sand, the IVa bonitation class (USDA 2006). The soil from the experiment was characterized by the following parameters: $\mathrm{pH}_{\mathrm{KCl}} 5.30 ; \mathrm{P}_{\text {avail }}=51.5 ; \mathrm{K}_{\text {avail }}=99.9$;
$\mathrm{Mg}_{\text {exchan }}=64.4 \mathrm{mg} \mathrm{kg}^{-1}$. The soil contained an average level of available phosphorus and exchangeable magnesium and low available potassium (PN-R-04023:1996, PN-R-04022:1996/ Az1:2002, ISO 13536:1995).

The experimental plant was winter rape, DK EXPLICIT hybrid. On the basis of the exploratory research results, the variety is included in the list of varieties recommended by COBORU. The plot area was $15 \mathrm{~m}^{2}$. The experiment was established using random blocks design in 4 replicates.

Two factors were compared in the studies: I. factor -3 two-component mineral fertilizers of Russian, Lithuanian and Polish production (POLIDAP $®)$. The fertilizers used were characterized by the same composition of NP $-18-46$. II. factor -3 doses of fertilization (minimum, optimum, maximum, which were: 1.0, 2.0, $3.0 \mathrm{dt}$ per hectare, respectively). The fertilization levels were calculated based on the soil fertility regarding phosphorus, i.e. the most expensive component. The minimum dose was $50 \%$ lesser than the optimum dose of $2.0 \mathrm{dt} \mathrm{P}_{2} \mathrm{O}_{5}$ per hectare, and the maximum dose was $50 \%$ higher. The potassium fertilization was applied in the form of $60 \% \mathrm{KCl}$ (potassium chloride) at the amount of $0.75,1.50$, $2.25 \mathrm{dt} \mathrm{K}_{2} \mathrm{O}$ per hectare, respectively.

POLIDAP $^{\circledR}$ is a fertilizer in a form of uniform gray granules, $2-5 \mathrm{~mm}$ in size, at least $92 \%$. Granules are coated, non-caking, with a homogeneous composition. POLIDAP ${ }^{\circledR}$ contains $18 \%$ nitrogen $(\mathrm{N})$ in ammonium form and $46 \%$ phosphorus $\left(\mathrm{P}_{2} \mathrm{O}_{5}\right)$ soluble in neutral ammonium citrate, i.e. available as one and diammonium phosphate. POLIDAP ${ }^{\circledR}$ contains $5 \%$ sulfur $\left(\mathrm{SO}_{2}\right)$ soluble in water in the form of sulfate. The producer of the fertilizer is Chemical Works "POLICE” S.A. - Police [https://nawozy.eu/nawozy/ wieloskladnikowe/polidap.html].

In subsequent years of experiment (2015, 2016 and 2017), during the cultivation of winter rape, the following agrotechnical measures were carried out. After harvesting the forecrop plant, which was oat, stubble cultivation was carried out using a stubble cultivator. Then, after about two weeks, moderate plowing was conducted using a rotary plow. Just before sowing, after manual application of fertilization with two-component fertilizers and potassium salt, the soil was treated with a cultivator with a string roller to a depth of about $8 \mathrm{~cm}$. The sowing was performed using a ØYORD seed drill on August 26. After 14 days 
from the sowing of rape, when seedlings developed at least one pair of specific leaves, herbicidal spraying was carried out (Metazanex $500 \mathrm{SC}$ $\left.2 \mathrm{dm}^{3} \mathrm{ha}^{-1}\right)$. Then, after about a week, insecticide protection was applied (Alstar Pro 100 EW 0.1 $\left.\mathrm{dm}^{3} \mathrm{ha}^{-1}\right)$, and after another 7 days, herbicidal treatment was completed to supplement selfseeding cereals and other monocot weeds (Supero $05 \mathrm{EC}$ ). The last treatment performed after the next 7 days was a fungicide treatment with a double action: fungicidal and regulating the plant conformation (Toprex $375 \mathrm{EC}$ at the dose of $\left.0.4 \mathrm{dm}^{3} \mathrm{ha}^{-1}\right)$.

In early spring, with the start of the vegetation period (about 3rd-4th March), the first nitrogen fertilization was carried out at the amount of 80 $\mathrm{kg} \mathrm{N} \mathrm{ha}{ }^{-1}$ in the form of ammonium nitrate. The second dose of nitrogen fertilization was applied in the phase of the third internode elongation (5-7 April) at the amount of $80 \mathrm{~kg} \mathrm{~N} \mathrm{ha}^{-1}$ in the form of ammonium nitrate.

Then, the first fungicide treatment was performed within a few days (Alstar Pro $100 \mathrm{EW}$ $0.1 \mathrm{dm}^{3} \mathrm{ha}^{-1}$ ). Subsequently, in the final stage of flowering, a combined insecticide and fungicide treatment was carried out (Trion $250 \mathrm{EW} 0.6 \mathrm{dm}^{3}$ $\mathrm{ha}^{-1}$ and Proteus 110 OD at the dose of $0.6 \mathrm{dm}^{3}$ $\left.\mathrm{ha}^{-1}\right)$. The harvest was carried out using a plot combine harvester after reaching the full rape seeds ripeness.

\section{Methodology of chemical analyzes}

The $\mathrm{pH}$ of the soil was determined potentiometrically, in accordance with the standard [ISO 10390/1994]. The available forms of phosphorus and potassium in the soil were determined applying the Egner-Riehm method [Egner et al. 1960]. In order to determine the content of exchangeable magnesium forms in the soil, a buffered barium chloride solution was used $(\mathrm{pH}=8.1)$ [ISO 13536:1995]. The magnesium content was determined in the extract obtained using the Atomic Absorption Spectrometer Apparatus (Thermo Fisher Scientific iCE 3000 Series).

The seed samples were wet mineralized in a mixture of nitric(V) and chloric(VII) acids in a 1:1 ratio [ISO 6869: 2000] to determine the total content of magnesium, potassium and sulfur. The metal content was determined spectrophotometrically. The content of sulfur was determined by means of CHNS elemental analyser (Costech International S.p.A. Italy)
After mineralization of rape seeds in a solution of sulfuric(VI) acid in combination with $\mathrm{H}_{2} \mathrm{O}_{2}$, nitrogen content was determined applying the Kjeldahl method [ISO 20483: 2013] and phosphorus using the colorimetric method with ammonium molybdate at $470 \mathrm{~nm}$ [ISO 6491: 1998].

\section{Statistical analysis}

The results were statistically processed with the analysis of variance, using 2-factors randomized blocks design. Confidence sub-intervals were calculated using Tukey's multiple test, assuming a significance level of $p=0.05$. In addition, the analysis of variance with regression for the main effect of quantitative factor - the dose of fertilizer - was performed for the selected soil features. The significance of regression equations was determined using the F-Fisher-Snedecor test. The regression lines are shown in figures. The statistical analysis of the results was carried out using the Statistica 10.0 software package.

\section{Climatic conditions}

The average annual temperature anomaly in 2015 calculated in relation to the years 1961-1990 reached $+2^{\circ} \mathrm{C}$. From July, heat waves began to appear in Poland, which ended only at the beginning of September, significantly hindering the post-harvest field work on the over-dried soil. August was the hottest, and temperatures in the case of winter rape cultivation are key, because the optimal date of sowing this plant in Poland falls in the second half of August. October was a cool month, and relatively high temperature of the air maintained in November 2015 created favorable conditions for winter crop growth and development. December 2015 turned out to be the hottest December in the history of instrumental measurements. Year 2015 was extremely dry. Extreme temperatures in summer, combined with the high insolation contributed to a significant increase in the sum of evaporation.

The weather course in February 2016 made a slight threat for plants and maintaining fairly high air and soil temperatures in January made some disturbances in winter plant dormancy. In March, the weather favored the field drying and soil warming, as well as vegetation. Cool days with deficient rainfalls in April inhibited the plant growth and development rate. The precipitation shortage caused that the water requirements of 
crops were not fully satisfied. Warm and sunny weather at the beginning of May favored the growth and development of plants. The status of many crops deteriorated resulting from a spring precipitation deficiency. The rainfalls recorded in June improved the soil moisture. Additionally, the precipitation in July was by about $30 \%$ greater in relation to many-year period. The autumn weather during the year in question was not favorable either. The rainfalls in August and September oscillated below the norm (by $60 \%$ and $30 \%$, respectively when compared to many-year period), which made the soil preparation and winter rape sowing remarkably difficult.

The mean air temperature in 2017 amounted to $8.9^{\circ} \mathrm{C}$, which was slightly higher (by $0.2^{\circ} \mathrm{C}$ ) than average for many-year period equal to $8.7^{\circ} \mathrm{C}$. August appeared to be the warmer month, while January was the coolest. In April 2017, cold days with rainfall significantly slowed the rate of growth and development of rape, which usually at that time began intensive flowering. In the second half of June, heavy rainfall caused an excessive waterlogging of the soil, making it difficult to perform the chemization treatments [http://old.imgw.pl/].

\section{RESULTS AND DISCUSSION}

\section{Soil acidity}

The soil $\mathrm{pH}$ before the experiment was $\mathrm{pH}_{\mathrm{KCl}}=5.30$ and according to the current standards, it was acidic soil (ISO 10390/1994). Introduction of two-component fertilizers was the factor causing acidification of the soil, rather than the differences between fertilizers (Table 1). The diversity of fertilizers doses did not affect the significant changes in the experimental soil $\mathrm{pH}$ (Table 2).

\section{Available phosphorus and available potassium}

Rape is a crop sensitive to deficiency of nutrients, which refers to the winter rape (Brassica napus L.); therefore, appropriate fertilization is necessary [ $\mathrm{Li}$ et al. 2017]. After the experiment was completed, the amount of available phosphorus in the soil of the control object was $46.2 \mathrm{mg} \mathrm{P} \mathrm{kg}^{-1}$, and the soil remained the moderately abundant. The application of different fertilizers did not change the content of available phosphorus in the soil significantly. After the harvest, the content of available phosphorus in the soil remained at an average level [PN-R-04023:1996]. There was no interaction between fertilizers and applied doses, so the main effects of doses were presented in Table 2. Diversification of twocomponent fertilizer doses was reflected in a significant increase in the amount of available phosphorus for plants to the level of $55.7 \mathrm{mg} \mathrm{P} \mathrm{kg}^{-1}$ soil. Using successive doses, a gradual increase in the amount of available phosphorus in the soil by $14.1 \%, 3.4 \%$ and $2.2 \%$ was obtained (Table 2 , Figure 1). The presented results indicate that increasing the dose of fertilizer by $50 \%$ caused an increase in the content of the available phosphorus, but it was not proportional to the dose. The above-mentioned dependence is clearly visible in the presented chart (Figure 1). Tujaka and Gosek [2009] reported a similar relationship - increasing the dose of phosphorus significantly reduced the percentage utilization of this component by plants.

Potassium has been the most deficient basic nutrient in Polish agriculture for over 20 years. The soil from the object without fertilization after rape harvest contained $71.9 \mathrm{mg} \mathrm{K} \mathrm{kg}^{-1}$ and it was a low-abundant soil in terms of the available potassium. The use of the same fertilizer in the form of potassium salt in the experiment

Table 1. Comparison of fertilizer effects on changes in $\mathrm{pH}$ value as well as available phosphorus and potassium contents and exchangeable magnesium in the soil, average from 2 years

\begin{tabular}{|c|c|c|c|c|}
\hline \multirow{2}{*}{ Parameters } & \multicolumn{3}{|c|}{ Fertilizers } & \multirow{2}{*}{$\operatorname{LSD}_{0,05}$} \\
\hline & Russian & Lithuanian & Polish - POLIDAP ${ }^{\circledR}$ & \\
\hline $\mathrm{pH}_{\mathrm{H} 2 \mathrm{O}}$ & 5.51 & 5.75 & 5.74 & n.s. \\
\hline $\mathrm{pH}_{\mathrm{KCl}}$ & 4.79 & 5.15 & 4.87 & n.s. \\
\hline \multicolumn{5}{|c|}{$\left[\mathrm{mg} \mathrm{kg}^{-1}\right]$} \\
\hline Available phosphorus/ $\mathrm{P}_{\text {avail }}$ & 50.7 & 55.9 & 56.2 & n.s. \\
\hline Available potassium $/ \mathrm{K}_{\text {avail }}$ & 104.9 & 102.0 & 112.0 & n.s. \\
\hline Exchangeable magnesium/Mg $\mathrm{Mexchan}$ & 54.6 & 54.1 & 49.3 & n.s. \\
\hline Sum & 210.2 & 212.0 & 217.5 & - \\
\hline
\end{tabular}

n.s. - not significant difference 
Table 2. Comparison of fertilizer doses effects on changes in $\mathrm{pH}$ value as well as available phosphorus and potassium contents and exchangeable magnesium in the soil, average from 2 years

\begin{tabular}{|c|c|c|c|c|c|}
\hline \multirow{2}{*}{ Parameters } & \multicolumn{4}{|c|}{ Dose $\left[\mathrm{dt} \mathrm{ha}^{-1}\right]$} & \multirow{2}{*}{$\mathrm{LSD}_{0,05}$} \\
\hline & 0 & 1 & 2 & 3 & \\
\hline $\mathrm{pH}_{\mathrm{H} 2 \mathrm{O}}$ & 5.64 & 5.73 & 5.63 & 5.64 & n.s. \\
\hline $\mathrm{pH}_{\mathrm{KCl}}$ & 5.15 & 5.01 & 4.90 & 4.90 & n.s. \\
\hline \multicolumn{6}{|c|}{$\left[\mathrm{mg} \cdot \mathrm{kg}^{-1}\right]$} \\
\hline Available phosphorus/ $\mathrm{P}_{\text {avail }}$ & 46.2 & 52.7 & 54.5 & 55.7 & 4.53 \\
\hline Available potassium $/ \mathrm{K}_{\text {avail }}$ & 71.9 & 95.5 & 105.4 & 117.9 & 12.6 \\
\hline Exchangeable magnesium/ $/ \mathrm{Mg}_{\text {exchan }}$ & 53.2 & 53.5 & 53.7 & 50.8 & n.s. \\
\hline Sum & 190.8 & 201.7 & 213.6 & 224.4 & - \\
\hline
\end{tabular}

n.s. - not significant difference

did not cause a change in soil classification and it was a factor making no differentiation regarding the changes in the amount of available potassium [PN-R-04022: 1996+Az1:2002] (Table 1). The potassium availability for plants, taken in the form of a cation, is subject to different rules than the phosphorus taken in the anionic form. The chemistry of potassium in soils is relatively simple, compared to that of nitrogen and phosphorus [Syers 2005].
Introducing fertilizer in the form of potassium salt into the soil caused an increase in the content of available potassium, but it did not change its classification as to its abundance. The amount of potassium fertilizer had a significant impact on the amount of available potassium in the soil. By grading its dose, significant increases in the amount of available potassium by $32.8 \%, 10.3 \%$ and $11.8 \%$ was obtained (Table 2, Figure 2). The effect of increase the dose on the content in the

a)

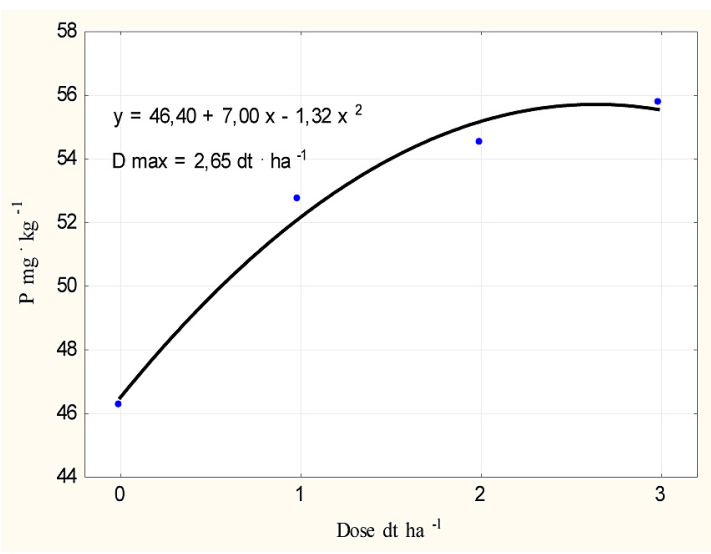

b)

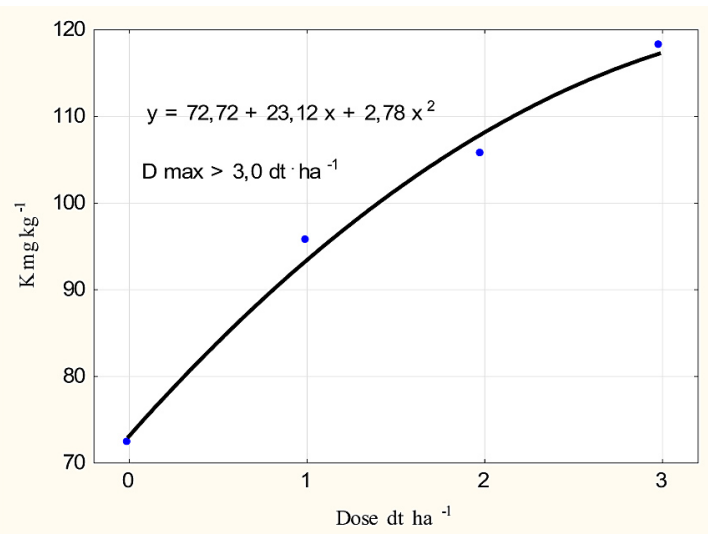

Figure 1. Regression equation between fertilizer dose vs. contents of available phosphorus and potassium in the soil 
soil was smaller at higher doses. The obtained results analyzing the so-called dilution effect are documented in the literature pertaining to the impact of the fertilizer use on the changes in the content of potassium available in soil [Lehmann et al. 1991, Kaczor and Zakorczmenna 2003, Syers 2005, Jadczyszyn et al. 2010].

\section{Exchangeable magnesium}

The content of exchangeable magnesium in the soil before the experiment start was $64.4 \mathrm{mg}$ $\mathrm{Mg} \mathrm{kg}^{-1}$. After the harvest of rape, the soil from all objects was characterized by the average abundance of exchangeable magnesium at the level of $50 \mathrm{mg} \mathrm{Mg} \mathrm{kg}^{-1}$ [ISO 13536:1995]. Introduction of two-component fertilizers into the soil as well as increasing their doses did not differentiate the content of exchangeable magnesium in the soil (Tables 1 and 2).

\section{The content of macroelements in winter rape seeds}

While analyzing the mineral composition of winter rape seeds (Brassica napus L.) as a tool for forecasting the oil yield, Szczepaniak et al. [2017] reported the maximum amount of nitrogen in rape seeds at $37.3 \mathrm{~g} \mathrm{~N} \mathrm{~kg}^{-1} \mathrm{DM}$. The content of nitrogen in rape seeds cultivated in the objects with fertilization using two-component fertilizers was at the same level. As a result of the same percentage of nitrogen content in the compared fertilizers, a uniform amount of nitrogen in seeds of cultivated winter rape was obtained (Table 3 ). It should be noted that rape seeds growing in nonfertilized objects contained $10 \%$ less nitrogen (Table 4). The effect of nitrogen fertilization expressed by the increase in the amount of nitrogen in rape has a definite confirmation in a number of studies on this issue [Kotecki 2001, Narits 2010, Öztürk 2010, Szczepaniak 2014].

Barłóg and Grzebisz [2000], based on the results from the experiment involving winter rape of Lirajet cv., stated that the phosphorus content in the ripe rape seeds was $7.7 \mathrm{~g} \mathrm{P} \mathrm{kg}^{-1} \mathrm{DM}$. The phosphorus abundance in the rape seeds of the hybrid variety DK EXPLICIT grown in the experiment was analogous (Table 3 ).

Under the conditions of the experiment conducted by Spiak et al. [2007] it was found that the average potassium content in seeds of three winter rape varieties ranged from 6.3 to $7.0 \mathrm{~g} \mathrm{~K} \mathrm{~kg}^{-1}$ in dry matter. Rape seeds grown in the experiment were characterized by higher potassium content (average $8.9 \mathrm{~g} \mathrm{~K} \mathrm{~kg}^{-1} \mathrm{DM}$ ).

Lack of variation in the contents of available phosphorus and potassium in the soil, depending on the fertilizer used (POLIDAP $\AA$, Russian or Lithuanian), was a factor that affected the same content of these macroelements in winter rape seeds. The increase in the content of available phosphorus and potassium in the soil as a result of different doses of fertilizers also increased the amount of phosphorus (27\%) and potassium $(8 \%)$ in the seeds of cultivated rape, but it was difference only between variant zero and all doses (Table 4).

The seeds of rape grown in the experiment were characterized by the magnesium content of $2.5 \mathrm{~g} \mathrm{Mg} \mathrm{kg}^{-1} \mathrm{DM}$. This is the value reported in a number of other studies on this issue [Korol et al. 1994, Barłóg and Grzebisz 2000, Szczepaniak et al. 2017].

Sulfur, being a part of some amino acids, is one of the most important nutrients for cruciferous plants. The sulfur content in rape seeds ranged from 3.38 to $3.59 \mathrm{~g} \mathrm{~S} \mathrm{~kg}^{-1} \mathrm{DM}$. For comparison, Chwil [2016] obtained the values regarding Kana $\mathrm{cv}$. in the range from 3.66 to $4.22 \mathrm{~g} \mathrm{~S} \mathrm{~kg}^{-1} \mathrm{DM}$.

Diversified doses of the compared two-compound fertilizers and potassium salt as well as their origin did not affect the changes in the abundance of winter rape seeds in terms of magnesium and sulfur (Tables 3 and 4).

\section{CONCLUSIONS}

1. Introducing the two-component fertilizers and diversification of their doses was a factor that did not change the soil acidification.

2. The applied two-component fertilizers (Russian, Lithuanian and Polish POLIDAP $\left({ }^{\circledR}\right)$ caused an increase in the amount of available phosphorus in the soil, with no differences depending on the fertilizer type.

3. Diversification in the doses of two-component fertilizers and potassium salt was reflected in a significant, but not proportional to the dose, increase in the amount of available phosphorus and potassium in the soil.

4. Introduction of two-component fertilizers to the soil, as well as increasing their doses did not differentiate the amount of exchangeable magnesium and sulfur in the soil and did not 
Table 3. Comparison of the effect of fertilizers on changes in the content of phosphorus, potassium and magnesium in rape seeds, average from 2 years

\begin{tabular}{|c|c|c|c|c|}
\hline \multirow{2}{*}{ Element } & \multicolumn{3}{|c|}{ Fertilizers } & \multirow{2}{*}{$\operatorname{LSD}_{0,05}$} \\
\hline & Russian & Lithuanian & Polish - POLIDAP ${ }^{\circledR}$ & \\
\hline \multicolumn{5}{|c|}{ [g kg ${ }^{-1}$ s.m.] } \\
\hline Nitrogen & 37,1 & 36,7 & 36,3 & n.s. \\
\hline Phosphorus & 7,77 & 7,24 & 7,51 & n.s. \\
\hline Potassium & 8,88 & 8,96 & 8,90 & n.s. \\
\hline Magnesium & 2,56 & 2,53 & 2,61 & n.s. \\
\hline Sulfur & 3,47 & 3,59 & 3,32 & n.s. \\
\hline Sum & 59,78 & 59,02 & 58,64 & - \\
\hline
\end{tabular}

n.s. - not significant difference

Table 4. Comparison of the effect of fertilizer doses on the changes in the content of phosphorus, potassium and magnesium in rape seeds, average from 2 years

\begin{tabular}{|c|c|c|c|c|c|}
\hline \multirow{2}{*}{ Element } & \multicolumn{4}{|c|}{ Dose [dt ha-1] } & \multirow{2}{*}{$\mathrm{LSD}_{0,05}$} \\
\hline & 0 & 1 & 2 & 3 & \\
\hline \multicolumn{6}{|c|}{$\left[\mathrm{g} \mathrm{kg}^{-1} \mathrm{DM}\right.$} \\
\hline Nitrogen & 33.7 & 36.2 & 36.7 & 37.2 & 1.58 \\
\hline Phosphorus & 6.03 & 7.38 & 7.45 & 7.68 & 0.744 \\
\hline Potassium & 8.29 & 8.93 & 8.87 & 8.94 & 0.573 \\
\hline Magnesium & 2.50 & 2.61 & 2.56 & 2.53 & n.s. \\
\hline Sulfur & 3.38 & 3.58 & 3.48 & 3.32 & n.s. \\
\hline Sum & 53.9 & 58.7 & 59.06 & 59.67 & - \\
\hline
\end{tabular}

n.s. - not significant difference

affect the changes in the content of these elements in seeds.

5. Using fertilizers of Russian, Lithuanian and Polish production (POLIDAP $®$ ) during rape cultivation, there was no difference in the nitrogen, phosphorus, magnesium and sulfur contents in the seeds of cultivated winter rape of hybrid DK EXPLICIT cv.

\section{REFERENCES}

1. Barłóg P., Grzebisz W., 2000. Growth dynamics, yield and nutrients uptake by winter oilseed rape fertilized with three types of nitrogenous fertilizer and a method of the second nitrogen rate division [in Polish]. Rośliny Oleiste, 21, 85-97.

2. Chwil S., 2016. The effect of foliar feeding under different soil fertilization conditions on the yield structure and quality of winter oilseed rape (Brassica napus L.). Electronic Journal of Polish Agricultural Universities. 19(3), Available Online: http:// www.ejpau.media.pl/volume19/issue3/art-02.html

3. Egner H., Riehm H., Domingo W., 1960. Untersuchungen über die chemische Bodenanalyse als Grundlage für die Beurteilung des Nährstoffzustandes der Böden. II. Chemische Extraktions- methoden zur Phosphor- und Kalium Bestimmung. Kungliga Lantbrukshögskolans Annaler. 26, 199-215.

4. ISO 10390/1994 Soil quality - Determination of $\mathrm{pH}$.

5. ISO 13536:1995 - Soil quality - Determination of the potential cation exchange capacity and exchangeable cations using barium chloride solution buffered at $\mathrm{pH}=8,1$.

6. ISO 20483:2013 - Cereals and pulses -- Determination of the nitrogen content and calculation of the crude protein content -- Kjeldahl method.

7. ISO 6491:1998 - Animal feeding stuffs - Determination of phosphorus content - Spectrometric method

8. ISO 6869:2000 - Animal feeding stuffs -- Determination of the contents of calcium, copper, iron, magnesium, manganese, potassium, sodium and zinc -- Method using atomic absorption spectrometry.

9. Jadczyszyn T., Kowalczyk J., Lipiński W., 2010. Fertilizer recommendations for field crops and permanent grasslands in Puławy. Teaching materials [in Polish], 95, 1-24. Wyd. IUNG-PIB, ISBN 978-983-7562-054-2.

10. Kaczor A., Łaszcz-Zakorczmenna J., 2002. Conten of different forms of nitrogen in spring barley 
depending on the lavel of fertilization with sulfur and potassium [in Polish]. Acta Agrophysica. 1(4), 667-672.

11. Korol W., Jaśkiewicz T., Bartuzi G., Bogusz G., Niescior H., Grabowski C., Mojek E., 1994. Chemical composition of rape seed from low glucosinolate varieties grown in Poland. Journal of Animal and Feed Sciences. 1994;3(1):57-64: https://doi. org/10.22358/jafs/69819/1994

12. Kotecki A., Malarz W., Kozak M., Aniołowski K., 2001. Influence of nitrogen fertilisation on chemical composition of spring rape five cultivars [in Polish]. Rośliny Oleiste. 22, 81-89.

13. Lehmann K., Matłosz C,. Stachowiak J., Wysocka G., 1991. Effect of the grass species and the potassium and nitrogen fertilization on the potassium form in soil [in Polish]. Roczniki Gleboznawcze. 17(3/4), 71-75.

14. Li H., Lu J., Ren T., Li X., Cong R., 2017. Nutrient Efficiency of Winter Oilseed Rape in an Intensive Cropping System: A Regional Analysis. Pedosphere. 27(2), 364-370. doi.org/10.1016/ S1002-0160(17)60324-2.

15. Narits L., 2010. Effect of nitrogen rate and application time to yield and quality of winter oilseed rape (Brassica napus L. var. oleifera subvar. biennisAgronomy Research (Special Issue 3), 671-686.

16. Nogalska A., Sienkiewicz S., Czapla J., Skwierawska M., 2012. The effect of multi-component fertilizers on the yield and mineral composition of winter wheat and macronutrient uptake. Journal of Elementology 17(4), 629-628. DOI: 10.5601/ jelem.2012.17.4.06

17. Öztürk Ö., 2010 Effects of Source and Rate of Nitrogen Fertilizer on Yield, Yield Components and Quality of Winter Rapeseed (Brassica napus L.). Chilean journal of agricultural research 70(1), 132-141.

18. PN-R-04022:1996/Az1:2002 - Agricultural chemical analysis of the soil - Determination of available potassium in mineral soils.

19. PN-R-04023:1996 - Agricultural chemical analysis of the soil - Determination of available phosphorus in mineral soils.

20. Regulation (EC) No 2003/2003 of the European Parliament and of the Council of 13 October 2003 relating to fertilisers. OJ L 304, 21.11.2003.

21. Spiak Z., Piszcz U., Zbroszczyk T., 2007. Disposition of nutrients in seeds and straw of selected winter rape cultivars. Part I. Macronutrients [in Polish]. Zeszyty Naukowe Uniwersytetu Przyrodniczego we Wrocławiu Rolnictwo. XC. 553, 93-106.

22. Statistics Poland, 2018. Statistical information, Crop production in 2017. Warsaw, ed. A. Łączyński.

23. Syers K.J., 2005. Soil and plant potassium in agriculture- a review. Fertilizers and Fertilization. 3(24), 9-36.

24. Szczepaniak W., 2014. A mineral profile of winter oilseed rape in critical stages of growth - nitrogen Journal of Elementology. 759-778. DOI: 10.5601/ jelem.2014.19.1.600.

25. Szczepaniak W., Grzebisz W., Barłóg P., Przygodzka-Cyna K., 2017. Minerale composition of winter oilseed rape (Brassica napus L.) seeds as a tool for oil yield prognosis [in Polish]. Journal of Central European Agriculture. 18(1), 196-213. DOI:10.5513/JCEA01/18.1.1879.

26. Tujaka A., Gosek A., Gałązka R. 2011. Estimation of Hedley's fractionation method applicability to the determination of changes in phosphorus fractions in soil [in Polish]. Pol. J Agron. 6, 52-57.

27. USDA 2006. United States. Department of Agriculture-Handbooks 1-690.

28. http://old.imgw.pl, 10.04. 2018.

29. https://nawozy.eu/nawozy/wieloskladnikowe/ polidap.html 